\title{
Covid-19: why we need a national health and social care service
}

\author{
Neglect of social care during the pandemic shames the UK
}

\section{Allyson M Pollock professor of public health ${ }^{1}$, Luke Clements Cerebra professor of law and social justice ${ }^{2}$, Louisa Harding-Edgar academic fellow in general practice ${ }^{3}$} ${ }^{1}$ Faculty of Medical Sciences, Newcastle University, Newcastle upon Tyne, UK; ${ }^{2}$ School of Law, University of Leeds, Leeds, UK; ${ }^{3}$ Institute of Health
and Wellbeing, University of Glasgow, Glasgow, UK; Correspondence to: A Pollock Allyson.Pollock@newcastle.ac.uk

Covid-19 outbreaks in care homes expose serious inadequacies in social care services across the UK. Data from across the world show that deaths from covid-19 mainly occur among older people, particularly those over $80 .{ }^{1}$ By 12 April 10612 deaths had been reported in the $\mathrm{UK}^{2}-40 \%$ of deaths have occurred in those aged $60-79$ and $52 \%$ in those 80 years or over. ${ }^{3}$

Close to 1.5 million vulnerable people are currently self-isolating indoors for 12 weeks. ${ }^{4}$ These include many older people and people with disabilities and chronic illnesses. Many are essentially in solitary confinement. Many residents in care homes are trapped in their rooms, with no visits from relatives and minimal interactions with staff. The decision to exclude relatives means that care homes have become closed institutions, increasing the risk that people are inappropriately denied hospital admission as well as the risk of neglect and abuse. ${ }^{56}$ Of equal concern are plans to transfer patients recovering from covid-19 from the NHS into empty nursing home beds. ${ }^{7}$

\section{Privatised, fragmented}

Social services in the UK are among the most privatised and fragmented in the Western world. They have been underfunded for decades. Between 2010-11 and 2017-18 local authority spending on social care in England fell by $49 \%$ in real terms, ${ }^{8}$ while privatisation increased. ${ }^{8}$ The UK has 5500 providers operating 11300 care homes for older people, and $83 \%$ of care home beds are provided by the for-profit sector. ${ }^{9}$ Responsibility for funding has been shifted to individuals, and there has been tightening of NHS and local authority eligibility criteria, as well as long delays in assessing eligibility and inconsistent and inequitable application of criteria. ${ }^{10}$

Care services in England employ roughly 1.6 million care staff ( 1.1 million full time equivalent), of which $78 \%$ are employed by the independent sector. ${ }^{11}$ Pay is low; $24 \%$ of people working in adult social care are on zero hour contracts, and in March 2019 around a quarter were being paid the national living wage of $£ 7.83$ an hour or less. ${ }^{12}$

Staff on zero hour contracts do not receive sick pay and often go to work when sick. The sector is 120000 workers short, ${ }^{13}$ and agency staff moving from one home to another further increases the risk of covid-19 transmission. Social care has been a low priority for personal protective equipment despite the high risks for residents and staff. ${ }^{14}$

\section{Irrational response}

Emergency legislation in the UK has severely curtailed the legal rights to social care services of elderly, ill, and disabled people in the community and in residential settings. ${ }^{15}$ In place of the duty to meet all essential social care needs, the coronavirus act substitutes a minimal obligation not to cut support below the level required to maintain their most basic human rights.

The Disability Law Service, a charity providing free legal services to disabled people, has condemned this action, stating that a rational response would have been to "radically redress the care and support deficits of the past decade, rather than take the action that is mandated by the 2020 Act." ${ }^{\prime 6}$ The service concluded that the action was contrary to international law_constituting "regressive" social care legislation targeting those least able to cope-and made no strategic sense.

Lack of access to essential social care (including for example, support after hospital discharge and mental health services) as well as the impact from the loss of routine NHS services will simply lead to more health crises, more hospital admissions, and more essential workers, including NHS staff, having to take time off work to care for family members.

The government has had to use emergency powers to overcome the fragmentation of health services caused by the Health and Social Care Act 2012 in England. ${ }^{17}$ That there are no equivalent emergency powers in social care legislation is a testimony to the state's abandonment of responsibility for this vital sector.

A substantial proportion of the NHS workforce is currently off work $\left(14 \%\right.$ in $\left.\mathrm{Scotland}^{18}\right)$. The extra capacity available to health services through flexible redeployment of staff is simply unavailable in the social care sector despite government advice that "Care home providers are advised to work with local authorities to establish plans for mutual aid, including sharing of the workforce between providers, with local primary and community health services providers, and with deployment of volunteers where that is safe to do so."19 


\section{Integrate health and social care}

The current emergency has exposed once again the need for a universal integrated health and social care service: radical action is required to bring all services and staff back under government control in a national and publicly accountable system so that high quality care is delivered by a trained and properly equipped workforce with decent terms and conditions of service.

A national health and social care system would (among many things) mandate the collection of vital data quantifying the effect of covid-19 on the social care sector-data on the number of cases and deaths by age, gender, ethnicity (minority groups are overrepresented among deaths and cases), and care setting, stratified by local authority area, ward, and general practice. An integrated system would allow detailed monitoring of staffing levels, sickness levels, the use of agency staff, and hospital admission rates for staff, residents, and other vulnerable groups. Accurate, timely data are key to controlling this pandemic.

What is needed - and what is so obviously lacking —is a plan of action. A plan to temporarily relocate care home residents to safe, infection-free accommodation allowing visitors; to provide covid-only facilities with extra staff support for those who do not need hospital admission; to ensure adequate levels of trained staff in all facilities, with adequate protective equipment; and to implement comprehensive contact tracing and testing of suspected cases in staff and residents. Above all we need a plan to transform our shameful social care system: a system that fails those in need, fails carers (paid and unpaid), and shames the UK.

Competing interests: We have read and understood BMJ policy on declaration of interests and have no interests to declare.

Provenance and peer review: Not commissioned, not externally peer reviewed

Verity R, Okell LC, Dorigatti I, etal . Estimates of the severity of coronavirus disease 2019 a model-based analysis. Lancet Infect Dis 2020;30:S1473-3099(20)30243-7. [Epub ahead of print]. 10.1016/S1473-3099(20)30243-7. 32240634
2 Public Health England. Covid19: track coronavirus cases. 12 Apr 2020. https://www.gov. uk/government/publications/covid-19-track-coronavirus-cases

3 NHS England. Covid 19 daily deaths, 11 Apr 2020. https://www.england.nhs.uk/statistics/ statistical-work-areas/covid-19-daily-deaths/

4 UK Government. Major new measures to protect people at highest risk from coronavirus. Press release, 6 Apr 2020. https://www.gov.uk/government/news/major-new-measuresto-protect-people-at-highest-risk-from-coronavirus]

5 Spanish army finds care home residents "dead and abandoned." BBC News 2020 Mar 24. https://www.bbc.co.uk/news/world-europe-52014023

6 McMichael TM, Currie DW, Clark S, etal . Epidemiology of covid-19 in a long-term care facility in King County, Washington. N Engl J Med 2020 [Epub ahead of print]. 10.1056/NEJMoa2005412 32220208

7 Department of Health and Social Care, NHS England, CQC, Public Health England. Admission and care of residents during covid-19 incident in a care home. 2 Apr 2020. https://www.gov.uk/government/publications/coronavirus-covid-19-admission-and-careof-people-in-care-homes accessed 10th April 2020

8 National Audit Office. Adult social care at a glance 2018. https://www.nao.org.uk/wp content/uploads/2018/07/Adult-social-care-at-a-glance.pdf

9 Competition and Markets Authority. Care homes market study: final report. 2017. https:/ /assets.publishing.service.gov.uk/media/5a1fdf30e5274a750b82533a/care-homes-marketstudy-final-report.pdf

10 House of Commons Committee of Public Accounts. NHS continuing healthcare funding. 13th report of session 2017-19. 2018. https://publications.parliament.uk/pa/cm201719/ cmselect/cmpubacc/455/455.pdf

11 Skills for Care. The size and structure of the adult social care sector and workforce in England, 2019. 2019. https://www.skillsforcare.org.uk/adult-social-care-workforce-data/ Workforce-intelligence/publications/national-information/The-size-and-structure-of-theadult-social-care-sector-and-workforce-in-England.aspx

12 Skills for Care. The state of the adult social care sector and workforce in England. 2019.

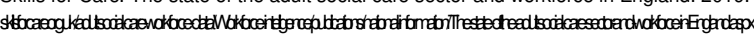

13 King's Fund. International recruitment in adult social care, 6 Nov 2019. https://www. kingsfund.org.uk/projects/nhs-in-a-nutshell/social-care-staffing-numbers

14 Holt A. Coronavirus: nearly 400 care groups 'face protection shortages.' BBC News 2020 Apr 5. https://www.bbc.co.uk/news/health-52174520

15 Coronavirus Act 2020. Chapter 7. http://www.legislation.gov.uk/ukpga/2020/7/introduction/ enacted

16 Disability Law Service. Coronavirus act threatens care for disabled people. https://dls.org uk/coronavirus-act-threatens-care-for-disabled-people/

17 Department of Health and Social Care. The exercise of commissioning functions by the NHS Commissioning Board (Coronavirus). Directions given to the NHS Commissioning Board 23 March 2020. https://www.gov.uk/government/publications/the-exercise-ofcommissioning-functions-by-the-nhs-commissioning-board-coronavirus-directions-2020

18 Coronavirus: Almost half of NHS Scotland staff absences covid-19 related. BBC News 2020 Apr 2. https://www.bbc.co.uk/news/uk-scotland-52133634

19 Public Health England COVID-19: Guidance on residential care provision. 6 Apl 2020. https://www.gov.uk/government/publications/covid-19-residential-care-supported-livingand-home-care-guidance/covid-19-guidance-on-residential-care-provision\#steps-carehome-providers-can-take-to-maintain-services

Published by the BMJ Publishing Group Limited. For permission to use (where not already granted under a licence) please go to http://group.bmj.com/group/rights-licensing/ permissions 